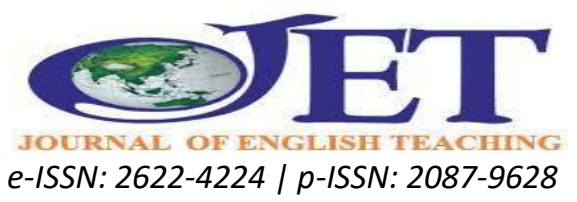

\title{
Developing Computer-Based Instructional Media for English Speaking Skill at Senior High School
}

\author{
Farida Noor Rohmah \\ faridanoor88@unisayogya.ac.id \\ Universitas 'Aisyiyah Yogyakarta
}

\begin{abstract}
This research aimed at developing computer-based instructional media using Adobe Flash for the tenth graders'English speaking skill material. The studyemployed research and development method. The results showed (1) the product is a computer-based instructional media in a combined format of tutorial and drilling facilitating semiinteractive learning consisting of thanking, complimenting, congratulating, surprise and disbelief materials; (2) the expert validation showed that the product quality in terms of media is categorized very good (4.51) and in terms of the material and instructionalare categorized good (3.91). The results of the field trials showed that the quality of the product in terms of material, media, and instructional is categorized very good (4.32). In conclusion, the developed media is eligible to be implemented in speaking learning activities.
\end{abstract}

Keywords: computer-based instructional media; Adobe Flash; speaking skill

\section{INTRODUCTION}

For its contributions, computer-based instructional media has been increasingly varied used as the medium of learning English a foreign language. Some software used are Microsoft PowerPoint (Lari, 2014; Scarsbrook, Graham, Perriss, 2006), Adobe Flash(Dewintha, Mering, \& Astuti 2018; Sorapure, 2016; Darmawan,2012; Sutopo, 2003), and others. In addition to its variation, computer-based instructional media have some advantages to support the learning process. The advantages of computer-based instructional media not only lie in the speed factor to get the information they offer but also the provision of multimedia which facilitates the presentation of learning materials and media in interesting, visual and interactive way.

Adobe Flash, formerly named Macromedia Flash, is one of the computer software that includes in Adobe system product. It is an animation software application used for the Web. With Adobe Flash, the media can be equipped with several kinds of animation, sound, interactive animation and others. The resulted images from Adobe Flash can be converted into other formats to be used on making web designs (Sutopo, 2003). With its use, the usual material concepts conveyed only with verbal forms can be gained with a visual form. Adobe Flash also makes the material more interesting to deliver because the material can be packed with a variety of animations. In addition, it 
also has its own programming language called ActionScript which enables the animation to be generated more interactive (Darmawan, 2012).

Despite many given advantages, the Adobe Flash is still not utilized optimally by the teacher as a medium of English teaching, especially on the teaching of speaking skill. Altough similar studies on developing Adobe Flash Media were reported by Dewintha, Mering, and Astuti (2018), Sorapure (2016), Supomo (2003) their reports were not dealt with students' need analysis of SMA N 1 Ngemplak in learning English speaking. Dewintha, Mering, and Astuti designed Adobe Flash media to teach Dayak traditional music, and Sorapure studied Adobe Flash in composition, and Supomo only reviewed interactive flash media in general.

To respond to such gap, the current report was to develop the adobe Flash media used in teaching English speaking. Using the students' need analysis, it applied a research and development research.

\section{LITERATURE REVIEW}

\section{The Teaching of English Speaking}

Apart from writing ability, speaking skill is grouped into productive skill. It is productive (Bailey, 2004; Zhihong, Leijuan, \& Xiaohui, 2010; Nunan 2015), since it is used to produce messages in the speakers' talk. Such productive skill enables the listeners grasp the speakers' emotion, feelings, and thought.

Regardless of being categorized as productive skill, speaking is different from writing. In linguistic features, Dakhi and Hutabarat (2018) characterized speaking as communicative, efficient, and effective occurances, and Bailey (2004) featured it as auditory, temporary, prosodic, immediate, and planned and editing limited.

Table 1:

Spoken and Witten Language Characteristics (Bailey, 2004)

\begin{tabular}{ll}
\hline \multicolumn{1}{c}{ Spoken Language } & \multicolumn{1}{c}{ Writen Language } \\
\hline Auditory & Visual \\
Temporary; immediate reception & Permanent; delayed reception \\
Prosody (rhythm, stress intonation) & Punctuation \\
Planning and editing limited by channel & Unlimited planning, editing, revision \\
\hline
\end{tabular}

Considering its differences, it is certain to teach the speaking skills based on its tenets. According to Nguyen (2015), these are (1) integrate cultural component or contexts (Nunan, 1999), (2) build confidence and motivation, (3) respond to students' needs and expectation, (4) allow spontaneity and flexibility in the teaching plan, and be sensitive to students' ability. As for teaching L2 speaking, it is more likely to (5) promote vocabulary mastery and (6) focus on sytactical competence. Finally, it is obliged to (6) harmonious and cooperative, and (7) require security and trust (Farrel \& Vos, 2018).

\section{Current Trend in Computer-Based Instruction}

Learning English using computer-based media has some advantages. Previous study showed that computer-based instructional media can enhance the students' performance in English (Wang \& Liao, 2017). Students using Computer-Assisted Language Learning (CALL) had better learning performances than those in traditional collaborative learning. Other study by Shyamlee and Phil (2012) found that there were some advantages of using computer-based media $n$ teaching English, one of which was to 
promote students' motivation and learning interest, which can be a practical way to get them involved in the language learning.

Lee (2008) proved the significance of learning by using computer-based instructional media. Using 153 students at the Institute of Technology in Taiwan as participants, his study showed that students preferred pronunciation learning by using computer software rather than learning in the traditional way because the software could provide explicit feedback for them. In addition, the software could provide repetition so they can learn English pronunciation whenever they need. Another result was that CALL (Computer-Assisted Language Learning) could be an English learning strategy that decreased the problem of pronunciation learning faced by teachers whose students were low motivated and had poor pronunciation ability.

Computer-based instructional media provide learners with more concrete material compared to conventional media such as textbooks. The material can be presented in audio and visual form. Heinich et al. (1982) stated "We support a concrete basis for conceptual thinking and hence to reduce meaningless word responses of students" (p. 21). Audiovisual-looking media do provide more concrete conceptual thinking.Pardede (2012) supported this by accentuating that CALL enables teachers to assess the internet for obtaining a various collection of teaching materials and tools that meet their unique teaching situations needs, including texts, audio with accompanying workbooks, videotapes with student worksheets, various CALL programs for teleconferencing and so on.

In developing computer-based instructional media, the developers need to pay attention to the media quality criteria. Chee and Wong (2003), posited that the quality of computer-based instructional media could be assessed by considering three aspects: appropriateness, accuracy and clarity, and screen presentation and design. The aspect of appropriateness concerns with the requirement that the material must accord with the characteristics of the students, the school and the curriculum used. The aspect of accuracy, currency and clarity necessitates the material to be accurate, current, clear, valid and non-biased, and the level of difficulty is in accordance with the student's ability level. Finally, screen presentation and design require the harmony among the color combinations, images and writing on the slide show.

Various studies on English instructional media development using Adobe Flash have been conducted. However, studies focusing on the development of the media for speaking skill are rare. Lee's (2008) study investigated media development for pronunciation material. Salameh's (2011) study explored multimedia offline cell phone system development for English language learning, but it only focused on receptive skills, i.e., reading, listening, and grammar. To fill in the gap in the literature, this study focused on speaking skill material development namely language expression. It aimed to develop computer-based instructional media with Adobe Flash for speaking skills material that was packaged in the form of compact disk (CD). Once developed, the media was evaluated in terms of material, media, and instructional aspects based on validation and field trial.

\section{METHOD}

This research employed the research and development method. To get the model that suits the purpose of this study, the researcher adapted and incorporated two research development models. In the aspect of development research, the model proposed by Borg and Gall (1983, p.775) was adopted, while in the instructional design aspect, the 
model developed by Dick, Carey \& Carey (2009, pp. 6-8)was taken. Both development models were adapted to develop a simpler development process to meet this research needs.

\section{Research Setting and Participants}

The study was conducted at SMA N 1 Ngemplak in January to May 2016. The participants of this study were the tenth grade students of State Senior High School of 1 Ngemplak. The samples were taken using proportional random sampling technique by selecting students representing the students with high, medium and low learning achievement.

\section{Procedures}

The four stages of four stages of research and development method, i.e., the preliminary study, the development planning, the product development, and the product evaluation were implemented to conduct this study. In the preliminary study, the researcher carried out the need analysis and library study. The development planning includes the activities of determining the design of learning, determining the standards of competence, basic competencies, formulate indicators, determining materials, determining learning strategies, and determining the learning evaluation form. At the product development stage, the instructional media product design was developed by creating flowchart and storyboard, and the supporting materials such as images, video, audio and animation were collected. The collected materials were then arranged into Adobe Flash program based on the flowchart and storyboard that had been prepared.

In the product evaluation stage, the media was validated by media experts assessing the aspects of media and by material/content experts assessing the aspects of the material and instructional. After being revised based on the experts feedback, the media were trialed to the field. The product trial consisted of three steps: one-to-one trial of 3 students, small group trial of 12 students, and field trials of 30 students or 1 group. The students provide an evaluation on the media through a set of questionnaire.

Table 2:

Validation of Media Eligibility

\begin{tabular}{lll}
\hline \multicolumn{1}{c}{ Aspects } & \multicolumn{2}{c}{ Indicators } \\
\hline Display & A. & Adjustment of the font and size \\
\cline { 2 - 3 } & B. & Color selection accuracy \\
\hline & C. & Layout regularity \\
\hline & D. & Display attractiveness of opening slide \\
\hline E. & Screen design quality \\
\hline & F. & Music opening accuracy \\
\hline G. & Audio clarity \\
\hline H. & Video clarity \\
\hline I. & Images, graphic and animation accuracy \\
\hline J. & Button placement accuracy \\
\hline K. & Button size and color \\
\hline Programming & A. & Files usage ease \\
\hline & B. & Files duplication ease \\
\hline C. & Menu selection clarity \\
\hline & D. & Navigation usage clarity \\
\hline & E. & Button usage clarity \\
\hline
\end{tabular}

Instrument 
The validation checklist and media assessment questionnaire were adapted from BSNP instrument validation for English textbook, the components of developing unit proposed by Nunan (2004), and the criteria of computer-based instructional media developed by Chee and Wong (2003). The criteria usedby the experts to assess the media are listed in Table 2.

Table 2 shows the blueprint of the validation sheet given to the expert of the media. The criteria were based on the theory from Chee and Wong (2003). The criteria of media eligibility consisted of two main aspects namely display and programming.

Table 3:

Validation of Material/Content Eligibility

\begin{tabular}{|c|c|}
\hline Aspects & Indicators \\
\hline \multirow[t]{9}{*}{ Content Eligibility } & 1. Material and syllabus suitability \\
\hline & 2. Material or content truth \\
\hline & 3. Material depth \\
\hline & 4. Material update. \\
\hline & 5. Material sequences \\
\hline & 6. Material develop the ability to communicate in accordance with the context of the \\
\hline & 7. Topic and students suitability \\
\hline & 8. Example clarity \\
\hline & 9. Video and animation and material suitability \\
\hline \multirow[t]{7}{*}{ Activity Eligibility } & 1. Activity variation \\
\hline & 2. Activity ability to motivate students \\
\hline & 3. Activity and learning objective suitability \\
\hline & 4. Activity and syllabus (Standard competence and basic competence) suitability \\
\hline & 5. Activity sequences and learning step suitability \\
\hline & 6. Activity and learner-centered concept suitability \\
\hline & 7. The number of activity \\
\hline \multirow[t]{5}{*}{ Language Eligibility } & 1. Language ease to understand \\
\hline & 2. English Grammar accuracy \\
\hline & 3. Language is natural \\
\hline & 4. Spelling accuracy \\
\hline & 5. Punctuation accuracy \\
\hline Instructional & 1. Indicators clarity \\
\hline \multirow[t]{7}{*}{ Eligibility } & 2. The use of logical step in material delivery \\
\hline & 3. The exercise difficulty level and student level suitability \\
\hline & 4. Exercise and material suitability \\
\hline & Feedback for correct and incorrect answer \\
\hline & 6. Media ability to motivate students \\
\hline & 7. Eye catcher suitability \\
\hline & Exercise and conceptual understanding suitability \\
\hline
\end{tabular}

Table 3 shows the blueprint of the validation sheet given to the expert of material. The criteria were adapted from BSNP instrument validation for English textbook. It consisted of four main aspects namely content, activity, language, and instructional eligibility. The students, then, gave evaluation on the media as well using questionnaire. The evaluation given by students was based on the items in the following table.

Table 4:

Test Instrument Blueprint 


\begin{tabular}{lll}
\hline \multicolumn{1}{c}{ Aspects } & \\
\hline Material & 1. & Indicators \\
& 2. & Material clarity attractiveness \\
3. & Material completeness \\
4. & Material importance \\
5. & Material up-to-date \\
6. & Language clarity \\
7. & Exercise and students' level suitability \\
\hline Display & 1. Ease of reading the text \\
& 2. Color combination attractiveness \\
& 3. Picture attractiveness \\
& 4. Audio/video clarity \\
5. & Opening slide attractiveness as attention drawer \\
6. & Ease of Button usage \\
\hline Instructional & 1. The ability of the media to motivate the students. \\
2. Exercise accuracy to concept understanding \\
3. Learning instruction clarity \\
4. Feedback giving accuracy. \\
5. Learning competence formulation accuracy
\end{tabular}

Table 4 shows the blueprint of questionnaire given to the students who had the field trial. The criteria were adapted from BSNP instrument validation for English textbook and Chee and Wong (2003). It covers Materials, display and instructional aspects.

\section{Data Analysis Technique}

There were two kinds of data, first, qualitative data in the form of the result of interview, observation, as well as expert and student comments, and second, quantitative data that were obtained from validation sheet and media assessment questionnaire. The technique of data analysis was done by describing qualitative data. Then, the researcher calculated the result of quantitative data. The data was first in the form of score, converted into qualitative data (data interval) with scale five. The reference to the conversion was adapted from the score conversion by Sukarjo (2008, p.101).

In this research, the minimum value of product quality was"good" category, from media expert, material expert and students. In detail, the eligibility description of developed media products were:

1) "Very good" product quality was equivalent with "very eligible" criteria;

2) "Good" product quality was equivalent with "eligible" criteria;

3) "Adequate" product quality was equivalent with "adequate" criteria;

4) "Poor" product quality was equivalent with "poor" criteria;

5) "Very Poor" product quality was equivalent with "very poor" criteria..

\section{FINDINGSAND DISCUSSION} Preliminary Study

The product was developed based on the results of needs analysis through teacher interviews, questionnaires by students, and classroom observation. Here are the results of needs analysis:

1) The data obtained from the observation showed that the students were lack of motivation (Dakhi \& Damanik, 2018) in following the English language learning, especially speaking skill activities. The students looked less enthusiastic about 
learning English. Students looked less interested in the media (Sitompul \& Sihombing, 2017) used by teachers. This was because the teacher only delivered the material using instructional media in the form of textbooks (van den Ham \& Heinze, 2018). Without a good explanation and procedure, the teacher simply asked the students to do the exercises in the textbook.

2) Data obtained through the interviews showed that the teacher found it difficult to increase students' motivation and to deliverthe material due to her lack of instructional media that could improve the student's motivation. During this time, teachers only used textbooks as the main medium to convey the material. The teacher used her laptop and audio speakers to play audio dialogue examples. The teacher said that computer-based instructional media was one of the alternative instructional media could be used for learning speaking skills. The teacher wanted material that provided an example of a dialogue involving native speakers. Drilling was also required for students to master the materials and fluently used the expression they are learning.

3) The result of need analysis questionnaire given is summarized in Table 5 .

Table 5:

Test Instrument Blueprint

\begin{tabular}{lll}
\hline \multicolumn{1}{c}{ Statement/Question } & \multicolumn{1}{c}{ Yes } & No \\
\hline English speaking class is fun. & $67 \%$ & $33 \%$ \\
Is speaking skill important for you? & $100 \%$ & $0 \%$ \\
Does your teacher use instructional media in teaching speaking skill? & $100 \%$ & $0 \%$ \\
Does the media used by the teacher vary? & $37 \%$ & $63 \%$ \\
Does the media help you to learn speaking skill better? & $26 \%$ & $74 \%$ \\
Does the media motivate you to learn speaking skill? & $43 \%$ & $57 \%$ \\
Has your teacher ever used computer based media in teaching speaking skill? & $0 \%$ & $100 \%$ \\
Are you interested in using computer-based media in learning speaking? & $83 \%$ & $17 \%$ \\
\hline
\end{tabular}

Based on Table 5, it can be seen that the students, being very much influenced by media literacy (Dvorghets \& Shaturnaya, 2015)were interested to use computer-based instructional media in learning English speaking skills. In addition, regardless of the effectiveness of the computer-based instruction (Carter, 2019) the teacher had reported that it was not applied at all. As a result, no students' interest and learning attractiveness was experienced.

\section{Development Planning}

After analyzing the needs, the researcher conducted the next step namely development planning which consisted of:

1) Determining the competence standard (Fernández-Sanz, Gómez-Pérez, \&CastilloMartínez, 2017) and basic competence. Based on the curriculum, the researcher determined the media covered one competence standard of speaking skill namely "Expressing the meaning in transactional and interpersonal conversation in daily context. Meanwhile, the basic competenceswere expressions of thanking (complimenting), congratulating, and expression of surprise and disbelief.

2) Determining the learning indicators. The indicators were determined based on the basic competence in the syllabus.

3) Determining the learning material. Analyzed by the researcher as a lecturer who was more likely to have relationship with the learners (Bakadorova \& Raufelder, 2018), 
the learning materials were determined based on the identified students' needs. It consisted of four topics namely expressions of thanking (complimenting), congratulating, and expression of surprise and disbelief.

4) Determining the learning strategy. The students would have an English class in the computer laboratory and every student used one computer with teacher assistance.

5) Determining the learning evaluation. The evaluation was informally administered by giving preferable feedback (Masantiah, Pasiphol, \& Tangdhanakanond, 2018) to the students' work in the media.

\section{Product Development}

The next step was conducted by designing flowchart as well as storyboard. Flowchart is the program flow of the media. Meanwhile, storyboard is the visual design of the media. After making the flowchart and storyboard, the learning materials in the form of video, exercises, pictures, audio files were compiled using Adobe Flash CS 4 with the assistance of programmer. The last step was program documentation. The media was packed in the form of $\mathrm{CD}$ and it could be copied directly in computers as well. The initial product development result of this product contained:

1) Eye catcher or attention drawer (Bartlett, Graf, Hedger, \&Adams, 2019) in the form of blend of text, font, color, slide show and opening music (Miller, Miller, Turne, \&Evans, 2017).

2) Main Menu, in the form usage instructions, material submenu, profile, and, references.

3) Material 1, containing competence standard, basic competence, indicator, lead-in activity, thanking and complimenting materials and exercises.

4) Material 2 containing competence standard, basic competence, indicator, lead-in activity, congratulating material, and exercises.

5) Material 3 containing competence standard, basic competence, indicator, lead-in activity, expression of surprise and disbelief materials, and exercises.

6) Profiles containing profiles of product developers and supervisors.

7) References containing various sources of material contained in this CD.

Table 6:

The Summary of Expert Validation Result

\begin{tabular}{llll}
\hline \multicolumn{1}{c}{ Validation } & \multicolumn{1}{c}{ Aspects } & Score & Average \\
\hline Media & Display & 4.63 & 4.51 \\
Material & Programming & 4.40 & \\
& Content & 4.00 & 3.91 \\
& Activity & 3.85 & \\
& Language & 3.80 & \\
\hline
\end{tabular}

\section{Product Evaluation}

The media and material eligibility was the average of the total score of all indicators contained in the media and material eligibility assessment rubric. In detail the score of expert validation on each aspect can be seen in Table 6 .

As shown by Table 6, the results of media expert validation indicated that the quality of the validated aspects met the eligible criteria. The display aspect got a score of 4.63. The same thing was also shown in the score of programming aspects that obtained 4.40. The eligibility of the product was also indicated by the material expert 
validation. The products were feasible although it was not as high as media expert validation. All of the aspects included in good category. Aspect of content got score 4.00 while aspect of activity got score 3.85. The material expert gave 3.80 on the language aspect and 4.00 on the instructional aspect.Based on the overall results for media validation and material experts, the average score of material eligibility was 4.51 indicating 'very good' criteria and 3.91 for media eligibility, indicating 'good' criteria. It can be concluded that the media eligibility score was better than the material eligibility. However, both aspects were in good category to be tested in the field. To conclude, the designed product was found in line with Sorapure's (2016) Adobe Flash advantages.

Experts in addition to providing a quantitative assessment also provide suggestions for improvement for revised references. Table 7 below shows a summary of expert advice.

Table 7:

Summary of Expert Feedback

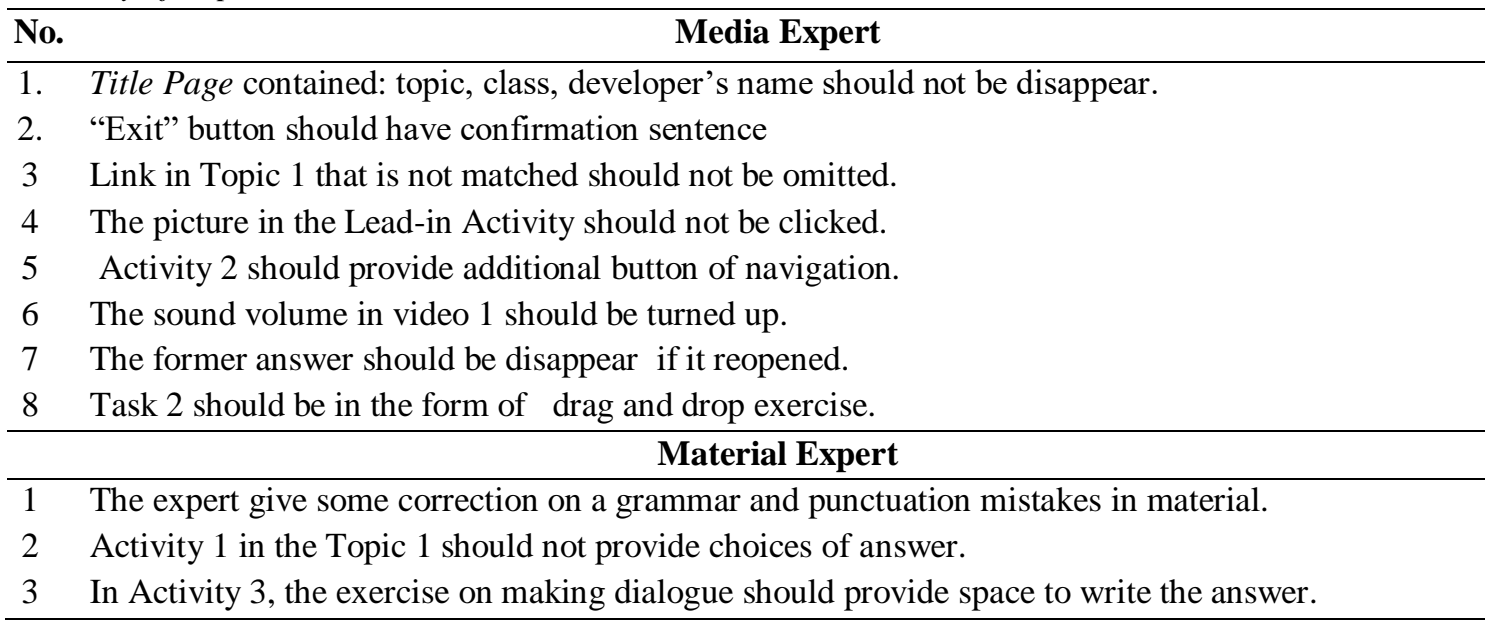

After being given expert validation, the product was tested in SMA $\mathrm{N} 1$ Ngemplak. Table 8 shows the overall results of the media assessment during the student trial.

Assessing students' perspective (Pilli, 2017) is known functional to gain access to their interest. In one-to-one trial, student ratings showed that the three aspects included in the three categories were score 4.09 on the material aspect, 4.28 score on media aspects, and 4.27 on instructional aspect. The overall average score was 4.21. Student suggestions serve as a basis for revising the product.

After the product was revised, the results showed that the average score of student ratings on the product changed from 4.21 to 4.27 with the 4.24 score for the material aspect, 4.29 for the media display aspect, and 4.28 for the instructional aspect. This showed that product quality was improved. 
Table 8.

Summary of Trial Results

\begin{tabular}{llcl}
\hline \multicolumn{1}{c}{ Trial } & \multicolumn{1}{c}{ Aspects } & Average score & Category \\
\hline On-to-one trial & Material & 4.09 & Good \\
& Media & 4.28 & Very good \\
& Instructional & 4.27 & Very good \\
& Average & $\mathbf{4 . 2 1}$ & Good \\
\hline Small group & Material & 4.24 & Very good \\
trial & Media & 4.29 & Very good \\
& Instructional & 4.28 & Very good \\
& Average & $\mathbf{4 . 2 7}$ & Very good \\
\hline Field trial & Material & 4.28 & Very good \\
& Media & 4.32 & Very good \\
& Instructional & 4.38 & Very good \\
& Average & $\mathbf{4 . 3 2}$ & Very good \\
\hline
\end{tabular}

The result of the field trial was similar to the previous trial. The overall average score increased from a small group trial of 4.27 to 4.32 (in the scale of 0.00 to 5.00) Researchers have made prior revisions based on student suggestions on small group trials so that the product quality improved. The overall average on field trial included in very good category with a score of 4.28 on the material aspect, 4.32 score on media display aspect, and score 4.38 on the instructional aspect. From the three times trials, the quality of the products including media, material, and instructional aspects, improved, as shown by the assessment scores in Figure 1.

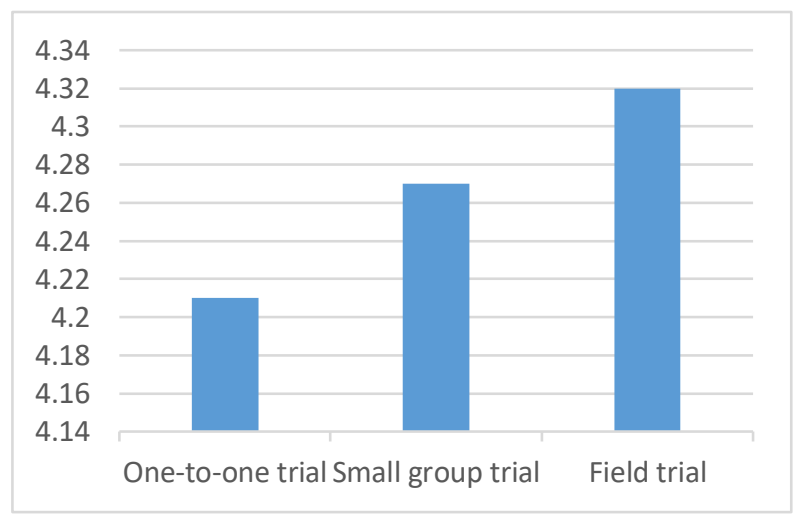

Figure 1: The result of media assessment by the students

The revision of the product was also based on the student's suggestion at the time of trial. In a one-to-one trial, the revision covers only two basic things, namely in Material 1 activity and the size of the font. In the third stage of revision, a fundamental revision was in Material 3 section. Based on the suggestion to add video, the researcher then added one video.

The fourth stage of revision was the latest revision of the series of product trials, namely field trials. After field trials, students suggested that instructions on using the $\mathrm{CD}$ should be changed to English language in order to be more challenging. However, in order to anticipate students with low English level, the instructions were changed into two languages. First, the instruction would be in English language. For the student who did not understand the instruction in English, the student could change the instruction 
option in Indonesian language. Another suggestion is about the packaging. Initially the developer only gave the $\mathrm{CD}$ with paper cover at the time of trial use. The students, then, recommended that the $\mathrm{CD}$ should be hard covered and should be given label or sticker so that the CD surface was more secure.

The product trial results showed a positive assessment and response to the product being developed. This could also be seen from the observation results during the trial process indicating that the students did not feel bored and active in following the learning of English lesson. The students were also enthusiastic in doing the exercises in the developed media.

In short, the developed product or media has several advantages as follows.

1) The product has a very good level of eligibility or eligibility. This was evidenced by the results of expert validation and trials that show that the average score ofthe material, media, and learning aspects were included in the very good criteria.

2) The product was easy to operate. It ca be used with auto-run facility (when the CD was inserted in the CD ROM, the program will directly operate). In addition the product can be used repeatedly so that students can review the existing material on the CD.

3) The product can be also directly copied and opened in the computer or laptop without using CD so it can be more practical.

4) This program size is relatively small but contains many topics or material including audio and video.

5) The exercises are more interesting with the example of videos of native speakers so that it is more challenging for students.

6) The existence of the display design and the picture makes the students become more enthusiastic and interested to learn.

After conducting a series of expert validation process and three-time trial process to students, as well as revisions, it was found that the Adobe Flash, the computer-based instructional media, productwas very feasible to use.Instead of providing female students' need (Trudeauet al, 2011) and designing multi-format web-based assessment (Kimet al 2011), the produced instructional media was intended to provide the students' need in general in English speaking learning.

Compared to Saputro, Muryani, and Sarwono's (2018) finding which was fair category, the current media was more likely to be better. Different from Pope et al's (2019) feasibility of smartphone application, the present product feasibility was found similir to Dewintha, Mering, and Astuti's (2018). It was reported that their Adobe Flash was appropriate to be used in Dayak traditional music teaching.

\section{CONCLUSION AND SUGGESTION}

The development of computer-based instructional media has been done with four stages: (1) preliminary study stage, (2) development planning, (3) product development, and (4) product validation. By going through these stages, a CD-based computer-based instructional media product has been produced in a composite format of tutorials and drilling that can be used as a medium for semi-interactive learning. The learning CD covers some speaking skill materials, namely the expressions of thanking, complimenting, congratulating, surprise and disbelief.

The result of validation of media expert showed that the quality of media aspect shows the product includes in very good category with the average score of 4.51 . 
Meanwhile, the result of validation based on the material expert shows that the product includes in good category with the average score of 3.91.

Based on the field trial, the quality of computer-based instructional media with Adobe Flash for English speaking skill of high school class X was very good with the score of 4.28; in terms of media display aspect is categorized very good with the score of 4.32; and viewed from the learning aspect of quality is categorized very good with the score of 4.38. referring to the results of the assessment, it can be concluded that the developed instructional media is very feasible to be used as a medium of learning English speaking skills class $\mathrm{X}$ in senior high students.

Based on the conclusions above, four suggestions are put forward: (1) English subject teachers are expected to use this media product as an example of a variety of instructional media products; (2) Ideally this product is used by students with the guidance of teachers because the media is not fully interactive; (3) This learning media is computer-based media. Thus, schools should complement the computer lab or language lab with headphones and speakers. At that time, the number of computers should be sufficient for the number of students of one class; (4) Other developers should refer to existing products in developing future learning products, especially on aspects that needs to be improved.

\section{REFERENCES}

Bakadorova, O., \& Raufelder, D. (2018). The essential role of the teacher-student relationship in students' need satisfaction during adolescence. Journal of Applied Developmental Psychology, 58, 57-65. https://doi.org/10.1016/j.appdev.2018.08.004

Bailey, K.M. (2004), Speaking, In D. Nunan, (ed.), Practical English Language Teaching, Higher

Education Press, Beijing.

Bartlett, L. K., Graf, E. W., Hedger, N., \&Adams, W. J. (2019). Motion adaptation and attention: A critical review and meta-analysis. Neuroscience \& Biobehavioral Reviews, 98, 290-301. https://doi.org/10.1016/j.neubiorev.2018.10.010

Borg, W.R., \& Gall, M.D. (1983). Educational Research: An Introduction. (4 ${ }^{\text {th }}$ ed.). New York: Longman.

BSNP. (2008). Instrument Validation for English textbook. Jakarta: Departemen Pendidikan Nasional.

Carter, M . D. (2019). The effects of computer-based simulations on speech-language pathology student performance. Joural of Communication Disorders, 77, 44-55. https://doi.org/10.1016/j.jcomdis.2018.12.006

Chee, T.S. \& Wong, A.F.L. (2003). Teaching and Learning with Technology. Singapore: Prentice Hall.

Dakhi, S. \& Damanik, I S. (2018). Students' Motivation in Reading English Text: A Qualitative Study in EFL Context. Journal of English Teaching, 4 (2), 81-93.

Dakhi, S. \& Hutabarat, H. (2018). Language effectivenes and factors influencing scinetific writing of Indonesia undergraduate thesis. Review: Joural of English Education, 7 (1), 61-74. https://doi.org/10.25134/erjee.v7i1.1496

Darmawan, D. (2012). Inovasi Pendidikan: Pendekatan Praktik Teknologi Multimedia dan Pembelajaran Online. Bandung: PT. Remaja Rosdakarya.

Dewintha, S., Mering, A., \& Astuti, I. (2018). The development of adobe flash to learning Dayak traditional music for students in junior high school. Journal of 
Teaching and Learning, 3 (2). Retrieved from http://journal.stkipsingkawang.ac.id/index.php/JETL/article/view/750/pdf

Dick,W., Carey, L. \& Carey J. O. (2009). The Systematic Design of Instruction $\quad$ (7th $^{\text {th }}$ ed.). New Jersey: Pearson.

Dvorghets, O. S., \& Shaturnaya, Y. A. (2015). Developing students' media literacy in the English language teaching context. Procedia-Social and Behavioral Sciences, 200, 192-198. https://doi.org/10.1016/j.sbspro.2015.08.051

Farrel, T. S., \& Vos, R. (2018). Exploring the principles and praticess of one teacher of L2 speaking: The importance of reflecting on practice. Iranian Journal of Language Teaching Research, 6(1), 1-15.

Fernández-Sanz, L., Gómez-Pérez, J., \&Castillo-Martínez, A. (2017). e-Skills Match: A framework for mapping and integrating the main skills, knowledge and competence standards and models for ICT occupations. Computer Standard \& Infereces, 51, 30-40. https://doi.org/10.1016/j.csi.2016.11.004

Heinich, R., et al. (1982). Media and the New Technologies of Instruction. Canada: John Wiley \& Sons Inc.

Kim, S., et al. (2011). The feasibility of a multi-format Web-based assessment of physicians' communication skills. Patient Education and Counceling, 84 (3), 359-367. https://doi.org/10.1016/j.pec.2011.04.003

Lari, F. S. (2014). The Impact of Using PowerPoint Presentations on Students' Learning and Motivation in Secondary Schools. Procedia-Social and Behavioral Sciences, 98 (6), 1672-1677. https://doi.org/10.1016/j.sbspro.2014.03.592

Lee, S.T. (2008). Teaching Pronunciation of English Using Computer Assisted Learning Software. Retrieved from http://www.ifets.info/journals/10_3/22.pdf in 3 July, 2018.

Masantiah, C., Pasiphol, S., \& Tangdhanakanond, K. (2018). Student and feedback: Which type of feedback is preferable?Kasetsart Journal of Social Sciences. https://doi.org/10.1016/j.kjss.2018.07.020

Miller, E., Miller, L., Turne, R. P., \&Evans, J. R., (2017). Neurologic Foundations of Music-Based Interventions. In More, K. S. (2018). Music Theraphy: Research and Evidence-Based Practice. 15-27. https://doi.org/10.1016/B978-0-32348560-9.00002-4

Nguyen, T. T. A. (2015). The Key Principles for Development of Speaking. International Journal on Studies in English Language and Literature (IJSELL), 3 (1), 49-53. Retrieved from https://www.arcjournals.org/pdfs/ijsell/v3-i1/8.pdf

Nunan, D. (1999) Second Language Teaching \&Learning. Massachusetts: Heinle\&Heinle Publisher.

Nunan, D. (2004). Task-Based Language Teaching. Cambridge Language Teaching Library: Cambridge University Press.

Nunan, D. (2015). Teaching English to speakers of other laguages. New York: Routlege. https://doi.org/10.4324/9781315740553

Pardede, P. (2012). Blended learning for ELT. Journal of English Teaching, 2(3), 165178.

Pilli, O. (2017). The Changes in Social Media Usage: Students' Perspective. The Anthropologist, $22 \quad$ (2), 345-354. https://doi.org/10.1080/09720073.2015.11891886 
Pope, Z. et al. (2019). Feasibility of smartphone application and social media intervention on breast cancer survivors' health outcomes. Transl Behav Med, 9 (1), 11-22. https://doi.org/10.1093/tbm/iby002

Salameh, S. (2011). A Multimedia Offline Cell Phone System for English Language Learning. International Arab Journal of e-Technology Vol 2 (1) pp, 44-48 https://core.ac.uk/download/pdf/25746112.pdf

Saputro, H. D., Muryani, C., \&Sarwono. (2018). The development of e-learning media with adobe flash program in contextual learning model to improve the students' learning outcome in the 10th grade of SMA Negeri 1 Sambumacan in 2917/2018. Jurnal GeoEco, 4 (2), 181-191. Retrieved from https://jurnal.uns.ac.id/GeoEco/article/view/23998/pdf

Scarsbrook, A. F., Graham, R. N. J. \&Perriss, R. W. (2006). Expanding the use of Microsoft PowerPoint. An overview for radiologists. Clinical Radiology, 61 (2), 113-123. https://doi.org/10.1016/j.crad.2005.10.004

Shyamlee, S.D., \& Phil, M. (2012). Use of Technology in English Language Teaching and Learning: An Analysis. Retrieved from: http://www.ipedr.com/vol33/030ICLMC-L10042.pdf in 3 July, 2018.

Sitompul, D. R. P, \& Sihombing, P. (2017). A teacching media of using the busy bit and SDCC in displaying character strig on LCD in MCU 8051IDE. Alexandria Engineering Journal, 57 (2), 813-818. https://doi.org/10.1016/j.aej.2017.01.037

Sorapure, M. (2016). Text, image, code, comment: Writing in Flash. Computers and Composition, 23 (4), 412-429. https://doi.org/10.1016/j.compcom.2006.08.001

Sukarjo. (2008). Kumpulan materi evaluasipembelajaran. Yogyakarta: ProdiTeknologi pembelajaran, PPs UNY.

Sutopo, A. H. (2003). Multimedia interaktif dengan flash. Yogyakarta: Graha Ilmu

Trudeau, K. J., et al. (2011). Identifying the Educational Needs of Menopausal Women: A Feasibility Study. Woman's Health Issues, 21 (2), 145-152. https://doi.org/10.1016/j.whi.2010.10.001

van den Ham, A. \& Heinze, A. (2018). Does the textbook matter? Longitudinal effects of textbook choice on primary school students' achievement in mathematics. Studies in Educational Evaluation, 59, 133-140. https://doi.org/10.1016/j.stueduc.2018.07.005

Wang, Y., \& Liao, H. (2017). Learning Performance Enhancement Using ComputerAssisted Language Learning by Collaborative Learning Group. Retrieved fromhttp://www.mdpi.com/2074-8994/9/8/141/pdfin 25 August, 2018.

Zhihong, L., Leijuan, H., \& Xiaohui, H. (2010). A research on a student-centred teaching model in an ICT-based English audio-video speaking class. International Journal of Education and Development using Information and Communication Technology, 6 (3), 101-123. 